1 Secretaria de Estado da Saúde de São Paulo (SES/ SP), Instituto de Saúde (IS) - São Paulo (SP), Brasil. ligia.duarte@uol.com.br

2 Universidade de São Paulo (USP), Faculdade de Saúde Pública (FSP) - São Paulo (SP), Brasil.

\section{Trends of commodification in the SUS of the state of São Paulo: territorial analysis of spending on agreements and management contracts with Social Organizations}

\author{
Tendências da mercantilização no SUS do estado de São Paulo: \\ análise territorial dos gastos com convênios e contratos de gestão com \\ Organizações Sociais
}

Ligia Schiavon Duarte', Jair de Abreu Leme Junior², Julia Amorim Santos ${ }^{\mathbf{2}}$, Luiz Victor Felipe ${ }^{\mathbf{1}}$ Áquilas Nogueira Mendes²

DOI: $10.1590 / 0103-11042020127021$

\begin{abstract}
National and international literature indicates a resizing of the private sector within the public health systems, providing its expansion and the establishment of new arrangements. The study aims to analyze the territorial dynamics in the process of explicit commodification in the state of São Paulo, identifying the territorial distribution of resources for the private management of public institutions and the contracting of non-profit institutions for the provision of health services. Budgeting information from the São Paulo State Department of Health was adopted from 2010 to 2017. Data analysis made possible to notice that a significant portion of health expenses was allotted to private management of public institutions (25.8\%) and to the supply of service by the contracting of non-profit institutions (12.0\%). Both spending actually increased over the period. The territorial analysis revealed that the contracting of private management is typical of the capital of São Paulo, while prevail in the other regions the expenses with the contracting of non-profit institutions for the provision of services. The State allot financial resources mainly for contracting the management of hospital equipment, followed by outpatient clinics.
\end{abstract}

KEYWORDS Health economics. Social Organization. Commodification. Health policy. Health management.

RESUMO As literaturas nacional e internacional indicam o redimensionamento do setor privado dentro dos sistemas públicos de saúde, com sua ampliação e constituição de novos arranjos. O trabalho objetiva analisar a dinâmica territorial no processo de mercantilização explícita no território do estado de São Paulo, identificando a distribuição espacial de recursos para a gestão privada de instituições públicas e a contratação de instituições sem fins lucrativos para a oferta de serviços. Recorreu-se às informações orçamentárias da Secretaria de Estado da Saúde de São Paulo, no período de 2010 a 2017. A análise dos dados permitiu observar uma participação relevante de despesas com gestão privada de instituições públicas (25,8\%) e com contratação de instituições sem fins lucrativos para oferta de serviços (12,0\%) nos gastos em saúde do estado, e o aumento real dos gastos em ambas as despesas ao longo do período. A análise territorial demonstrou que a contratação de gestão privada é um fenômeno característico da principal metrópole paulista, enquanto nas demais regiões prevalecem as despesas com contratação de instituições sem fins lucrativos para a oferta de serviços. Observa-se, também, que o estado despende recursos financeiros principalmente para a contratação da gestão dos equipamentos hospitalares, seguido dos ambulatórios.

PALAVRAS-CHAVE Economia da saúde. Organização Social. Mercantilização. Política de saúde. Gestão em saúde. 


\section{Introduction}

The Unified Health System (SUS) was created in 1988 with the aim to consolidate health policies as universal basic social right ${ }^{1}$. SUS is recognized as one of the most progressive public health policies in the world, which provides for care to every Brazilian or for anyone who is in the country, and grounded on guidelines for comprehensive care, where social participation and articulation of actions are carried out by means of regionalization and service networks.

To that end, the Federal Constitution of 1988, defined that the State must grant their own network of services without excluding the possibility that private entities participate whenever necessary. Thus, Article 197 made explicit that the Government should rule on regulation, supervision and control of actions and health services of public relevance, and that their enforcement should be carried out directly or by means of third parties, that is, by a person or a private company'.

Also, Law No. 8,080/1990 created a network of private services without links to public system called 'supplementary services' so to provide services to the population upon direct payment or by means of institutions intermediating the supply-consumer relation $^{2}$. The articulation between the public and private sectors grew endogenously within the public health policies in Brazil, and part of the literature suggests an intensification of the public-private arrangement over the 30 years of SUS existence ${ }^{3,4}$.

As from 1995, under President Fernando Henrique Cardoso term, the Public Administration Reform ${ }^{5}$ emphasized the need to modernize public administration so to become a regulator of economic activities and be efficient under market criteria. The main argument relied on the importance of integration in the world economy, with emphasis on the privatization of the industrial sector, although stressing the need for a certain mediation of the State in some social fields, such as education, health and culture. The process was harmonized with the consolidation of fiscal adjustment and a macroeconomic policy for the implementation of Plano Real, of restrictive nature, such as the cutting of public spending ${ }^{6}$. Under that proposal, the management reform aimed to modernize public administration by transforming what they called a bureaucratic-state framework into a managerial one, so to make public administration efficient under market criteria, while the State act as a regulator of economic activities.

The modernization proponents advocated that the increase in the public administration efficiency would be the result of a complex reform project of 'non-exclusive' services within the State. It was reaffirmed that the goods and services sector should be fully market-oriented, while production should, in principle, be carried out by the private sector. As for activities that could not be controlled exclusively by the market, the State should regulate and transfer resources to a legal entity classified as 'non-state public'?

The expression did not apply exclusively to Brazil. There is an international movement for which health systems have undergone reforms to introduce, albeit partially, market mechanisms ${ }^{8-10}$. Ferreira and Mendes ${ }^{11}$ recognize the importance of understanding the changing dynamics in universal health systems, viewing the specificity of each arrangement and local dynamics, broadening existing forms and creating new market mechanisms.

Federal Law No. 9,637/1998 approved the implementation of Social Organizations as 'new models of non-state management'12,13, concomitantly to the building of autonomous regulatory agencies. As for health, the National Health Surveillance Agency was created in 1999, as was the National Agency for Supplementary Health in $2000^{14}$, besides the approval of the Law of Fiscal Responsibility, formally named Supplementary Law (LC) No. 101, of 2000. The latter was guided by the economic agenda of the International 
Monetary Fund (IMF), which, among other things, defined limits to federated entities with personnel expenditures ${ }^{15,16}$. This conjoint of measures instituted over the State Reform period, intertwined in the context of an orthodox macroeconomic policy due to the institution of the economic tripod high interest rates, inflation targets, primary surplus and floating exchange rate, to value the Real against the Dollar - created the need to redesign the Brazilian social policies during the years $1990^{6,16}$.

The context of that new rationality of public spending profoundly affected social policies, particularly the health policy. Throughout the 1990s, the SUS implementation process and the decentralization strategy of its main guidelines was able, by itself, to introduce important changes in the policy organization. Health municipalization, particularly since 1996, foments numerous innovations related to the effectiveness and efficiency of the system management under different perspectives, among them the emergence of new actors municipal managers, state managers, councils, among others -, and the changing in the relation between public and private in the health system. If, on the one hand, the policy that builds SUS requires the State strengthening, on the other hand, the internal rearticulation of the private initiative in the health sector is grounded on technological modernization and on a supposedly efficiency and quality of services, attaining political power and social legitimacy ${ }^{\mathbf{1 7}}$.

As for Bodstein and Souza ${ }^{17}$, the new institutional design started to include numerous modalities of organization and management that enable private capital a diversified front of health actions, given the political arrangement in each local context. Modalities enjoying a relatively autonomy as for direct public funding, indirectly benefit from tax waivers or from the possibility of having their private clients served by means of public equipment of greater complexity. Others are built on direct public funding for the provision of health services, among them agreements with the public sector, and particularly with states and municipalities.

It is possible to affirm that the supply of health services has become an essential field for the development of a front for the private sector, even when considering countries traditionally recognized by their social protection systems $^{10}$. As for Pahim ${ }^{10}$, although the difficulties to precisely establish the boundaries between the public and the private in the prospects of the private sector profitability, the separation between supply and demand functions push providers towards a permanent search to expand their market niches so to preserve or expand their revenues.

In this context, Law No. 9,637/1998 creates the Health Social Organizations (OSS) model. The acceptance of OSS model by municipal and state managers stems from the greater administrative flexibility of rules imposed on the public entity, enabling the contracting of personnel at market conditions, the adoption of standards for purchases and contracts, and the wide flexibility in budgeting and financial enforcement ${ }^{\mathbf{1 8}}$. Conversely, it enables entities qualified as Social Organizations (OS) to fulfill the role of locus for capital appraisal. As for Morais et al. ${ }^{\mathbf{1 8}}$, the possibility of paying managers with public resources, of applying monetary surpluses following the capital financialization dynamics, and the placing of these entities among the largest companies in the country would qualify the sector as a component of the Health Industrial Economic Complex.

Despite the intense debate on the actual implementation results of a non-state public organization model aimed to absorb publishable activities ${ }^{10,18,19}$, governments of various ideological colors have adopted, in a variety of territories and fields of activity, general guidelines of the reform processes, following the political dynamic that converges to the use of similar instruments for the supply of public services in the context of the New Public Management. Indirectly governing the 
management instruments has been a global trend, and has been intensified at the level of states, particularly as to health policies in Brazil.

As for Alcântara ${ }^{\mathbf{2 0}}$ and Leite ${ }^{\mathbf{2 1}}$, the new organizational frameworks of public sector, particularly OSS, must be submitted to a continuous and deep process of evaluation, whilst an organizational design must be systematized so to create effective evaluation and control mechanisms. Management contracts have been identified as faulty in some aspects, requiring the improvement of techniques for measuring efficiency, control and especially the methods of external supervision. The authors reinforce that, to date, there are no reliable evaluations able to prove the greater efficiency of those new organizations.

The Brazilian administration is used to carry out under-planned and unreasoned reforms, leading to partial and unsatisfactory results whose only aim is to escape the alleged rigidity of the legal system, particularly the public administrative law. As per Mendonça and Machado 22, Corporate Governance practices are referenced in the principles of transparency, equity, accountability and ethics. The authors affirm that there must be, in third sector organizations, governance mechanisms able to be implemented so to achieve efficient social performance.

As from OSS choice to perform services within the management model, one of the main questions concerns the privatization possibility of the state units. Despite the trend, it has also been one of the factors of explicit resistance against the model by SUS political actors within the collegiate decisionmaking spaces ${ }^{23}$.

The fact is that Law No. 9,637/1998 generated an OSS remarkable concentration along the South-Southeast axis of the country, which is related to the dynamics of the economic region $^{18}$. The trend of regional concentration of public funding for the health sector ${ }^{\mathbf{2 4 , 2 5}}$ and of private health providers, especially the philanthropic ones ${ }^{\mathbf{1 0} 2 \mathbf{2 6}}$, in regions of greater economic development also over the country as in urban centers is a phenomenon already identified in the specialized literature.

Morais et al. ${ }^{\mathbf{1 8}}$ stand out that, in addition to being territorially concentrated, the capacity of the ten largest OSS, located in São Paulo and Rio de Janeiro, to expand themselves throughout the national territory, reaching adjoining or not localities, describes a movement suggesting the creation of monopolies. The authors also evince the increasing number of public institutions managed by OSS holding management contracts both at the state and municipal levels, from 2009 to 2016. Also, hospitals, mostly, carry the assistance profile of privately managed institutions, particularly general hospitals ${ }^{\mathbf{1 8}}$. Even considering that the assistance profile of privately managed institutions is largely comprised of hospital, it is possible to observe the expansion of the OSS model to outpatient units, clinical analyses and care centers for specific groups ${ }^{\mathbf{1 0}}$.

Pahim $^{10}$ analyzed the OSS implementation in the state of São Paulo and identified that, in addition to LC 846/98 authorizing the state government to qualify as 'social organizations' non-profit private entities focused on the areas of health and culture, LC 62/08 determined the expansion in scope of that management framework. The author ascertains that, during the period 1998-2007, the Health Ministry was privileged, and the OSS model developed in a context especially favorable as for funding conditions. She also confirms the tendency to increase spending on management contracts or agreements, with a significant precedence of OSS model in the budget of São Paulo State Department of Health (SES/SP) in the 2000s.

The author affirms that the implementation of OSS model by SES/SP followed three phases: i) 1998-2001 - the introduction of management in hospital units; ii) 2002-2004 - the introduction of a new format of management and interiorization contract for some hospitals in São Paulo; and iii) 2005-2008 - the incorporation of other types of health services to the roll of contracts and agreements with management entities. 
As indicated, this process of resizing public and private sectors followed by the creation of new institutional arrangements can be observed internationally. The literature brings the terms commodification, privatization and commercialization to absorb the increase of the private logic within public health systems, also by considering the increase in the direct participation of the private sector as a supplier of services and of funding private resources as by the adoption of private principles of management, remuneration and organization of systems $\mathrm{s}^{\mathbf{2 7} 28}$.

Ferreira and Mendes ${ }^{11}$ analyzed the insertion of market mechanisms in the health system reforms of Germany, France and the United Kingdom, adopting the term 'commodification' to characterize the process and identifying four trends combined in terms of explicit and implicit processes, which can occur both by funding and by supplying services. This study adopts as reference the trend identified as 'explicit commodification of service supply', which means the shift of responsibility from the public to the private sector as to the supply of services, particularly its incorporation in the supply of services and in the private management of public institutions.

As from the above, this work aimed to analyze the territorial dynamics in the process of explicit commoditization in the state of São Paulo. The goal was to verify the geographic distribution of resources towards the private management of public institutions and the contracting of non-profit institutions for the supply of services within that sphere of government. It started from the analysis of SES/ SP allocation of resources so to shed light on the dissemination of OSS model in São Paulo geographic area.

\section{Materials and methods}

This is a descriptive and exploratory study of quantitative nature and retrospective longitudinal approach. The information comprising the analysis were retrieved from the System of Information and Budget Enforcement (Sigeo), as for SES/SP health expenditures. It is understood that the larger the historical series the better the understanding of the spending trend. However, the analysis comprised the period from 2010 to 2017 , i.e., from the first year available in Sigeo database till the last closed year available at the time of the study.

Only the expenses classified in the health function 10 were retrieved from the Sigeo database. The concept of health expenditure is proposed by Mendes, Marques, Leite and Tubone ${ }^{29}$ and comprises all expenses on health services of universal access, involving the activities developed by SES/SP - government direct administration -, and transfers carried out to decentralized entities - Foundations and Autarchies, government indirect administration. Also, only the expenses derived from resources collected by the state government were accounted, that is, from the State Treasury, since their values are closed to the expenses linked to the mandatory percentage of the government revenue for health enforcement defined by Constitutional Amendment 29 (EC 29) ${ }^{30}$. Those expenses are circumscribed to the state management, without undergoing direct interference from the federal government's policy.

So to understand the dynamics related to the process of explicit commodification in the supply of services, some expenses were emphasized in the database: expenses related to the contracting of private management in the supply of services, i.e., OSS contracting for the management of state equipment identified as Management Contracts - LC 846/98 (item 3.3.90.39). In this study, those expenses were named 'OSS Management Contracts'. Furthermore, to identify the incorporation of the private sector in the supply of services, expenses classified in the application modality 50 were emphasized, referring to the 'Transfers to Private Non-Profit Institutions'. Their expense items were classified as follows: i) 
Item 3.3.50.43.79 - 'Agreements with social organizations'; ii) Item 3.3.50.43.74 - 'Agreements with non-profit colleges'; iii) Item 3.3.50.43.76 - 'Agreements with Santa Casas' (hospitals); and iv) Items 3.3.50.43.72, 3.3.50.43.75 and 3.3.50.43.90 - 'Other agreements'. The sum of expenses classified in these items was named 'Agreements'.

As for the expenditure analysis, the 'Liquidated Expenses' were regarded, indicating that the amounts do not include the so-called 'Remainders payable' of that same year, thus only including the expenses processed after the creditor's right confirmation. The values were deflated as per the General Price Index - Internal Availability (IGP/DI - Fundação Getúlio Vargas, of January 1993) and converted at a price as per December/2017 index, allowing for the comparison within the historical series in real value.

Sigeo database provides information on the expenses settled as per municipality in which the expenditure occurred. In a view to understanding the territorial dynamics of the expenditure accounting, data were retrieved by municipalities and were later coded by health regions respecting the resolution of the Bipartite Inter-managers Commission (CIB) No. 153, 2007, subsequently amended by CIB No. $4,2012^{31,32}$. The residual information in Sigeo database on municipalities belonging to other states of the federation was classified as 'Other States'.

As to analyze the spending territorial dynamics and in view of the importance of the Metropolitan Region of São Paulo (RMSP) as a privileged locus of expenses incurred in the contracting of non-profit institutions, this study chose to classify the six health regions located in RMSP - Alto do Tietê, Franco da Rocha, Grande ABC, Mananciais, Rota dos Bandeirantes and São Paulo - as 'Health Regions of São Paulo Metropolitan Region' , and the other 57 health regions of São Paulo as 'Remaining Regions'. In other words, the 63 health regions of São Paulo were classified into two groups: those belonging to
RMSP, named 'RMSP Health Regions', and those not belonging to the RMSP, named 'Remaining Regions'.

The information available in Sigeo database does not allow for the identification of the attention level of units under OSS management. For that reason, the Manager Financial Portal of the Budget and Financial Management Coordination of the State of São Paulo Department of Health (CGOF - SES/ SP) was adopted as a way to complement the analysis of territorial dynamics. Upon the portal, SES provides detailed consultations by type, object, source of funding, among others, of all transfers made by them. In 2017, it was possible to build a database containing also the transfers to OSS as the consolidated management contracts according to the manager and the contracted unit.

Such database was complemented with the OSS headquarter municipality and with the municipality in which the contracted unit is located. Afterwards, the municipalities were classified as belonging to the RMSP or as Remaining Regions. Finally, the units under contract were classified into: i) hospitals, ii) Specialty Medical Outpatient Clinic (AME), and iii) remaining units. For example, the latter includes the State Diagnostic Imaging Services (Serviços Estaduais de Diagnóstico por Imagem-Sedi), the Lucy Montoro Network, the Health Services Supply Regulation Center (Central de Regulação de Oferta de Serviços de Saúde-Cross), among others.

Following the database feeding in with the proposed classification, three contracted units were identified under two different OSS managements. For those three cases, management contracts of the contracted units were confirmed on the Transparency Portal of SES/ SP. The OSS records whose contracts could not be identified were deleted from the database. After that process of information assessment, the total amount of transfers to OSS increased from $\mathrm{R} \$ 4,857.20$ million in 2017 to $\mathrm{R} \$ 4,838.00$ million. The amounts of transfers recorded in the CGOF-SES/SP Manager Financial Portal 
(financial data) should not be compared to the values found in Sigeo (budget data), because it was exclusively useful as a parameter for the analysis of the dynamics of private management contracting of public institutions by SES/SP.

\section{Results and comments}

As can be inferred from table 1, SES spent $\mathrm{R} \$ 124.72$ billion of the state treasury within the period 2010-2017, of which $\mathrm{R} \$ 15.02$ billion were transferred to private non-profit institutions for the purchase of services under 'Agreements', and $\mathrm{R} \$ 32.2$ billion under 'OSS Management Contracts', equivalent to $12.0 \%$ and $25.8 \%$ of total expenditures, respectively. In 2017, the last year of the period analyzed, OSS Management Contracts equivaled to $28.5 \%$ of the total expenditures, while that amount equivaled to $23.7 \%$ in 2010 .

Table 1. State expenditures as per types of expenses and year, in the state of São Paulo, from 2010 to 2017

\begin{tabular}{|c|c|c|c|c|c|}
\hline \multirow[b]{2}{*}{ Year } & \multicolumn{2}{|c|}{ Agreements } & \multicolumn{2}{|c|}{ OSS Management contracts } & \multirow{2}{*}{$\begin{array}{l}\text { Total } \\
\text { Value }\end{array}$} \\
\hline & Value & $\%$ & Value & $\%$ & \\
\hline 2010 & $1,602,42$ & $11.5 \%$ & $3,301,77$ & $23.7 \%$ & $13,949,29$ \\
\hline 2011 & $1,757,49$ & $12.3 \%$ & $3,565,84$ & $24.9 \%$ & $14,333,42$ \\
\hline 2012 & $1,666,99$ & $11.2 \%$ & $3,972,20$ & $26.8 \%$ & $14,842,85$ \\
\hline 2013 & $1,774,74$ & $10.6 \%$ & $4,478,29$ & $26.7 \%$ & $16,776,91$ \\
\hline 2014 & $2,156,78$ & $13.1 \%$ & $3,972,72$ & $24.1 \%$ & $16,496,11$ \\
\hline 2015 & $1,964,12$ & $12.2 \%$ & $4,091,34$ & $25.3 \%$ & $16,144,88$ \\
\hline 2016 & $2,265,12$ & $14.4 \%$ & $4,122,03$ & $26.3 \%$ & $15,681,09$ \\
\hline 2017 & $1,836,21$ & $11.1 \%$ & $4,701,86$ & $28.5 \%$ & $16,500,35$ \\
\hline Total & $15,023,87$ & $12,0 \%$ & $32,206,05$ & $25,8 \%$ & $124.724,89$ \\
\hline
\end{tabular}

Source: Sigeo ${ }^{33}$.

Note: In Reais of Dec/2017. Deflated as per IGP-DI-FGV.

In fact, analyzing the expenditure behavior with 'OSS Management Contracts' and 'Agreements' over the analyzed period, one can note that both exhibit a real growth and that the first showed a higher increase than the latter, as can be depicted from the trend line in graph 1 . That finding shows that the increasing in the expenses with OSS model in the state budget, identified by Pahim ${ }^{10}$ in the mid-2000s, was carried on throughout the 2010s.
Breaking down the 'Agreements' analysis of expenses allows to observe that 'Agreements with Social Organizations', which accounted for the largest share within the aggregate at the beginning of the period, lost participation over time, becoming the smallest share in 2017. The remaining expenses with Agreements revealed a real increase over the period, with emphasis to expenses with 'Remaining Agreements' and, secondly, with 'Agreements with Santa Casas' (graph 1). 
Graph 1. State expenditures as per types of expenses and year, in the state of São Paulo, from 2010 to 2017
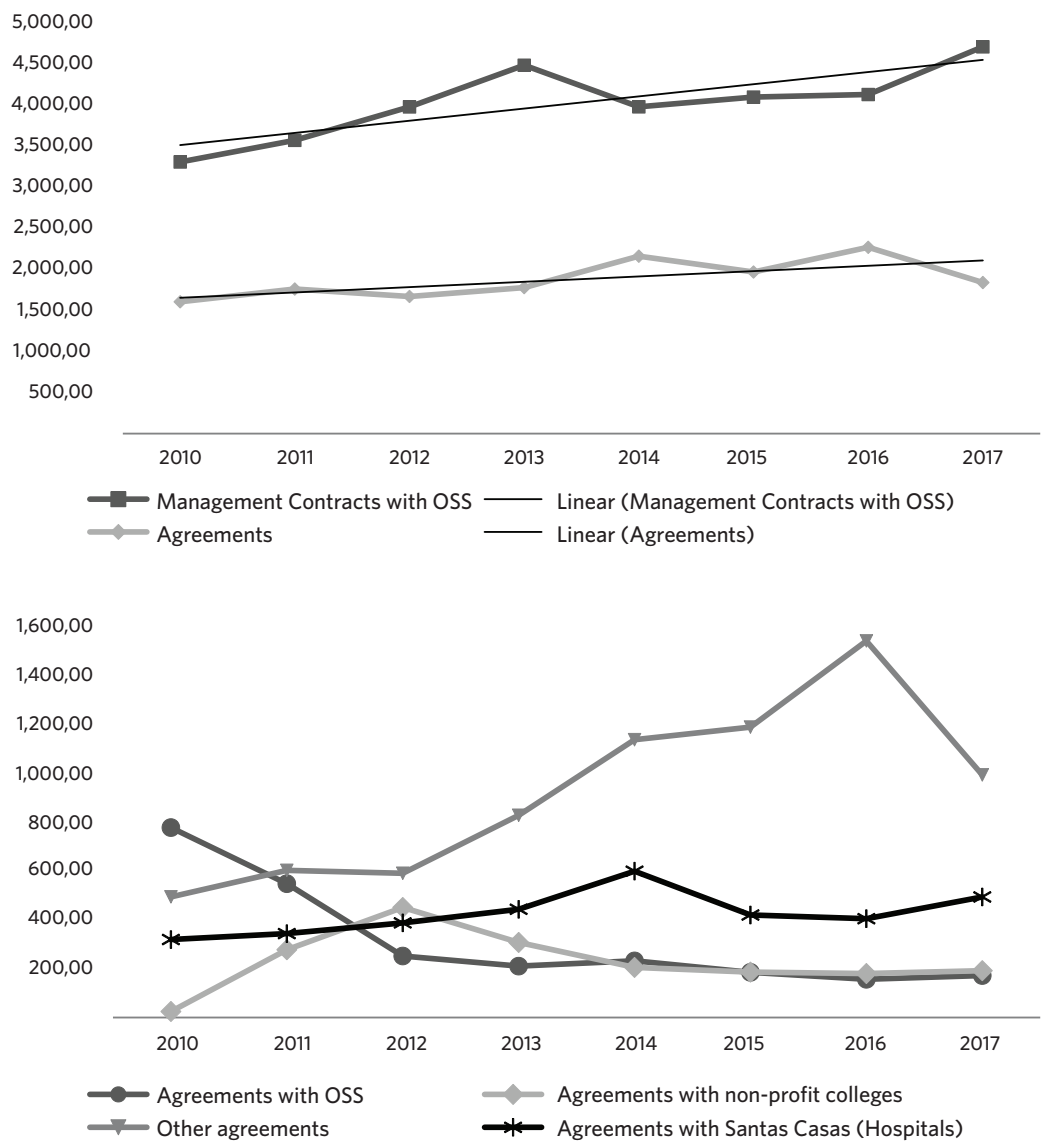

Source: Sigeo ${ }^{33}$.

Note: In Reais of Dec/2017. Deflated as per IGP-DI-FGV.

The analysis of resource allocation by SES/ SP indicates that, over the period 2010-2017, the explicit commoditization process in the supply of services increased. There was a real growth of expenses with agreements, meaning the incorporation of the private sector into the provision of services, although that expenditure is inferior to the private management growth of public institutions, when analyzed as for OSS management. Those findings demonstrate consonance with the broadening of the commodification process in the supply of services verified in core countries, more specifically, England, France and Germany ${ }^{11,34}$.
Resources amount spent within the period analyzed accounts for more than double the expenses with agreements, noting that the expenses with the contracting of private managers for public institutions decisively characterize the explicit commodification in the supply of services by the state of São Paulo. It also suggests the preeminence of OSS model as a market niche to maintain or increase the private sector profitability when compared to that of health service supply sector.

The territorial distribution spending with 'OSS Management Contracts' over the period analyzed allowed to verify that about $78.6 \%$ of those expenses are addressed to RMSP. As 
for expenses with 'Agreements', the situation is reversed, since $59.2 \%$ was carried out in the remaining regions. That result is due to the strong presence of 'Agreements with Social Organizations', 'Agreements with non-profit colleges' and 'Agreements with Santa Casas' in the remaining regions, which concentrated $72.6 \%, 96.4 \%$ and $72.4 \%$ of the expenses, respectively, in the health regions of that territorial cohort. Only the agreements classified as 'Other agreements' presented higher concentration in health regions compounding RMSP (table 2). One can also ponder the correlation found in the literature as to concentration in the territorial scope and in institutions, and to the broadening of monopolies ${ }^{18}$.

The expenses incurred with 'Agreements with Santa Casas' are widely distributed throughout the territory, being addressed to 60 of the 63 health regions of São Paulo State. The 'Agreements with Social Organizations' reached 12 health regions, while the 'Agreements with non-profit colleges' covered only six health regions: Guaraní Aquifer, Marília, Cuesta Cluster, São Paulo, Paraíba River Valley/Mountain Region and Metropolitan Region of Campinas. The latter is addressed about $66 \%$ of the total expenses with 'Non-profit college agreements'. Those data evidenced the importance of medical education institutions, mainly the public ones located in the largest regional clusters of the state, thus confirming the tendency to concentrate the transfer of public resources selectively in the territory, as for Duarte's ${ }^{\mathbf{2 4}}$.

Table 2. State expenditures by selected region and types of expenses, in the state of São Paulo, from 2010 to 2017

\begin{tabular}{|c|c|c|c|c|c|c|}
\hline \multirow[b]{2}{*}{ Expenses } & \multicolumn{2}{|c|}{ Remaining regions } & \multicolumn{2}{|c|}{ RMSP } & \multicolumn{2}{|c|}{ Total } \\
\hline & Value & $\%$ & Value & $\%$ & Value & $\%$ \\
\hline OSS Management Contracts & $6,889,37$ & 21.4 & $25,316,68$ & 78.6 & $32,206,05$ & 100.0 \\
\hline Total - Agreements & $8,891,68$ & 59.2 & $6,132,19$ & 40.8 & $15,023,87$ & 100.0 \\
\hline Agreements with OSS & $1,824,99$ & 72.6 & 687,41 & 27.4 & $2,512,40$ & 100.0 \\
\hline Agreements with non-profit colleges & $1,742,26$ & 96.4 & 65,02 & 3.6 & $1,807,28$ & 100.0 \\
\hline Agreements with Santas Casas (Hospitals) & $2,448,01$ & 72.4 & 935,39 & 27.6 & $3,383,40$ & 100.0 \\
\hline Other agreements & $2,876,43$ & 39.3 & $4,444,36$ & 60.7 & $7,320,79$ & 100.0 \\
\hline
\end{tabular}

Although expenses with 'OSS Management Contracts' are strongly concentrated in RMSP, the increase in the participation of those expenses in the remaining regions over the period analyzed is remarkably. Graph 2 shows a growth trend of expenses with
'OSS Management Contracts' in the remaining regions in comparison to RMSP growth trend. In fact, while the growth rate of RMSP expenses over the period $2010-2017$ was $2.7 \%$ per year, the remaining regions achieved $12.7 \%$ per year. 
Graph 2. State expenditures by type of expense as per selected regions and year, in the state of São Paulo, from 2010 to 2017

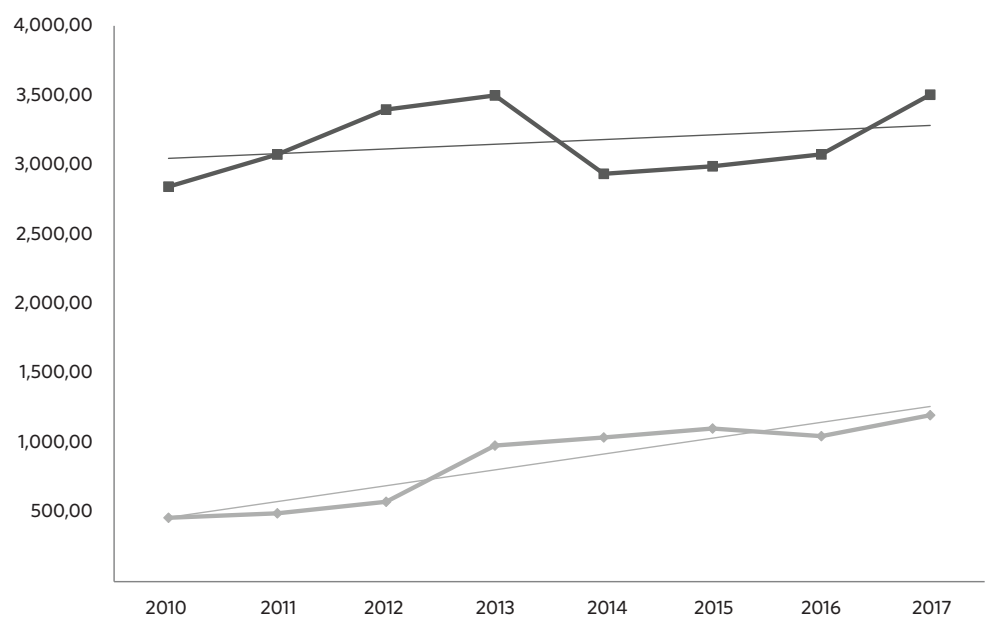

Source: Sigeo ${ }^{33}$.

Note: In Reais of Dec/2017. Deflated as per IGP-DI-FGV.

The expenses with the agreement evinced a real increasing over time, making possible to observe a shift in the profile of the non-profit institutions contracted. At the beginning of the period, agreements were made mainly with the OS, whilst institutions classified as 'Other Agreements' and 'Santa Casas' were prominent at the end of the period. On the other hand, while OS lost importance within the agreement expenses, the OSS expanded their participation in the budget enforcement of the state by means of expenses with management contracts of public institutions.

Regarding the territorial distribution of expenditures and the proposed territorial cohort, there is a strong concentration in the health regions that compound RMSP, resulting from the strong concentration of important private and public health institutions in the region. The contracting of private managers for the management of public institutions strongly evidences the commodification of RMSP service supply. The remaining regions have a higher relative participation in the expenses with agreements, that is, in the contracting of the private sector as a service provider. However, the greatest growth trend in expenses with 'OSS Management Contracts' in the remaining regions may reveal that the logic of contracting private management for public institutions is under a spreading process towards the interior, as study conducted by Morais et al. ${ }^{18}$.

According to information available in the Manager Financial Portal as of 2017, it is possible to identify 29 institutions qualified as OSS and contracted by the government of São Paulo State to carry out the management of 111 state health units spread out throughout São Paulo territory. Of the 29 OSS, 12 have their headquarters in RMSP, being ten in the city of São Paulo, one in the municipality of Santo André and one in the municipality of Cotia. The remaining 17 institutions are headquartered in 17 different municipalities located outside RMSP.

As for the 111 health units under OSS management, most of them are AME (57), followed by hospitals (31) and remaining units (23), as can be confirm by table 3 . However, the amounts transferred show the preponderance of hospitals in the allotment of resources, accounting for contracts that achieved 
$\mathrm{R} \$ 3,366.60$ million, of which $\mathrm{R} \$ 830.20$ million were addressed to the contracting of AME management and $\mathrm{R} \$ 641.20$ million to the remaining health units.

Thus, even if the direction of public resources for the contracting of private management for hospitals remains referred by various authors ${ }^{\mathbf{1 0}, 18,35}$, the assistance profile of institutions submitted to the OSS model is being diversified.

Concerning the territorial distribution, of the $\mathrm{R} \$ 4.84$ billion transferred in 2017, 72.6\% were allotted to the management of equipment located in RMSP. Such fact is mainly due to the contracting of private management for public hospitals, which are very concentrated in the RMSP (75.0\%). The resources transferred to the contracting of other health services are also strongly concentrated in RMSP (89.8\%), partially resulting from the existence of institutions providing strategic activities such as Cross and the State Center for Storage and Distribution of Health Supplies (Centro Estadual de Armazenamento e Distribuição de Insumos de Saúde-Ceadis), both located in the municipality of São Paulo, as revealed by Morais et al. ${ }^{18}$. The resources for AME contracting are better territorially distributed (table 3), suggesting that the territorial expansion observed for OSS model is also accompanied by the diversification of the assistance profile of the institution under private management.

Table 3. Health units and values transferred on by selected region and type of service, in the state of São Paulo, 2017

\begin{tabular}{lrrrrrrrrr}
\hline & \multicolumn{3}{c}{ Remaining regions } & \multicolumn{3}{c}{ RMSP } & \multicolumn{3}{c}{ Total } \\
Services & N & Value & $\%$ & N & Value & $\%$ & N & Value & $\%$ \\
\hline Total & 72 & $1,324,90$ & $27.4 \%$ & 39 & $3,513,10$ & $72.6 \%$ & 111 & $4.838,00$ & $100.0 \%$ \\
Hospital & 19 & 840,20 & $25.0 \%$ & 12 & $2,526,40$ & $75.0 \%$ & 31 & $3,366,60$ & $100.0 \%$ \\
AME & 43 & 419,40 & $50.5 \%$ & 14 & 410,80 & $49.5 \%$ & 57 & 830,20 & $100.0 \%$ \\
Other & 10 & 65,30 & $10.2 \%$ & 13 & 575,90 & $89.8 \%$ & 23 & 641,20 & $100.0 \%$ \\
\hline
\end{tabular}

Source: Portal Financeiro do Gestor ${ }^{36}$. (Manager Financial Portal).

The 2017 information retrieved from the Manager Financial Portal identifies public hospitals located in RMSP as the main health services under private management as per volume of resources transferred. But the strong presence of AME in health regions outside RMSP, along with the growth trend of expenditure with management contracts in those regions, as seen, may infer that the existence of a phenomenon similar to that identified in Germany and England. As for Ferreira and Mendes ${ }^{11}$, if public hospitals became privately managed in the early 2000s, already in the middle of the decade governments created new mechanisms to enable the change of management also in the outpatient sector.

\section{Final remarks}

This study made possible to qualify the commodification process undertaken by the São Paulo State government over the period 2010 to 2017, identifying the contracting of private management for the supply of services as its main characteristic. Both the expenses with 'OSS Management Contracts' and those with 'Agreements' exhibited real growth, the first showing a higher increase than the latter. The expenditure incurred with both expenses equivaled to $37.8 \%$ of the budget over the period, reinforcing the existence of an intense and increasing imbrication between private companies and public financing in the building 
of the São Paulo State health system, what is widely recognized by the literature ${ }^{10,18,19,35}$.

The territorial analysis showed that the contracting of private management is typical of the capital of São Paulo, while the other regions prefer the contracting of non-profit institutions for the supply of services. Nevertheless, the study evinced the higher relative growth of OSS contracting expenses for health service the management in regions not belonging to RMSP, indicating a territorial expansion trend of OSS model, as stated by Morais et al. ${ }^{\mathbf{1}}$, which may be concentrating in main regional economic clusters of the state, away from the capital of São Paulo24.

The information analysis suggests that the territorial expansion identified is accompanied by diversification in the assistance profile of the health unit under private management, especially AME', confirming the tendency of greater territorial spreading of less complex activities $^{\mathbf{2 6}}$. AME private management towards the interior of the state may indicate a strategy of territorial adequacy for maintenance or increasing in the profitability of the health sector private companies.

In other words, given the need of the private sector to expand its value and that, in Brazil, that need involves the designing of cross-subsidy projects ${ }^{10}$, the transfer of the OSS model to smaller urban centers and to fewer complex services is indispensable. As from that perspective, it would be expected that the trend of OSS model expansion deepened, particularly concerning the state main economic centers, as indicated by Duarte ${ }^{24}$, even if the efficiency of those arrangements was not proven.
This study reinforces the statement found in the literature of an intensification of the public-private arrangement in health policies in Brazil. As stated above, the articulation between the public and private sectors is built endogenously in public health policies in Brazil, issue sustained and reinforced also in the 1988 Constitution as in the 1995 Public Administration Reform. That resizing process of public and private sectors, followed by the creation of new institutional arrangements, can also be observed internationally.

Although not within the scope of this study, there is need to develop further research by deepening the analysis of this public-private resizing and its dynamics, as well as by evaluating the impact of that articulation on the attention network and health care. As from studies on the commodification process of public health policies in European countries, authors claim the risks of patient selection, possibly incurring in access inequity and damage to the system universalization ${ }^{8,11,28}$.

\section{Collaborators}

Duarte LS (0000-0001-5822-9033)*, Leme Junior JA (0000-0003-3882-0963)*, and Santos JA (0000-0002-4403-2165)* worked on data design, planning, analysis and interpretation; study outline; critical review of the content; and on the approval of the final version of the text. Felipe LV (0000-00034871-8145)* worked on data analysis and interpretation; and on the draft preparation. Mendes AN (0000-0002-5632-4333)* worked on the final approval of the manuscript. 


\section{References}

1. Brasil. Constituição (1988). Constituição da República Federativa do Brasil. Brasília, DF: Senado Federal; 1988.

2. Brasil. Lei no 8.080, de 19 de setembro de 1990. Dispõe sobre as condições para a promoção, proteção e recuperação da saúde, a organização e o funcionamento dos serviços correspondentes e dá outras providências. Diário Oficial da União. 19 Set 1990.

3. Santos IS. Evidência sobre o mix público-privado em países com cobertura duplicada: agravamento das iniquidades e da segmentação em sistemas nacionais de saúde. Ciênc. Saúde Colet. 2011; 16(6):2743-2752.

4. Santos JAA. Ampliação do Processo de Privatização da Saúde Pública no Brasil. São Paulo: Hucitec; 2018.

5. Behring ER, Boschetti I. Política Social: fundamentos e história. 8. ed. São Paulo: Cortez; 2011.

6. Modenesi AM. Regimes Monetários: teorias e a experiência do real. Barueri: Manoli; 2015.

7. Bresser Pereira LC. A Reforma do Estado nos anos 1990: lógica e mecanismos de controle. Lua Nova: Rev. de Cul e Pol. 1998; (45):49-95.

8. Jonathan F, Giovanella L, Konder M, et al. A “liberalização" do Serviço Nacional de Saúde da Inglaterra: trajetória e riscos para o direito à saúde. Cad. Saúde Pública. 2016; 32(8):e00034716.

9. Macedo ME, Alves AM. Reforma administrativa: o caso do Reino Unido. Rev. Serv. Púb. 2014; 48(3):62-83.

10. Pahim MLL. Organizações Sociais de Saúde do Estado de São Paulo: Inserção Privada no SUS e Gestão Financeira do Modelo pela Secretaria de Estado da Saúde. [tese]. São Paulo: Universidade de São Paulo; 2009.

11. Ferreira MRJ, Mendes NA. Mercantilização nas reformas dos sistemas de saúde alemão, francês e britânico. Ciênc. Saúde Colet. 2018; 23(7):2159-2150.
12. Andreazzi MFS. Teias e trama: relações público privadas no setor saúde. [tese]. Rio de Janeiro: Instituto de Medicina Social; 2002.

13. Correia MV, Santos VM. Privatização da saúde via novos modelos de gestão: as Organizações Sociais em questão. In: Bravo MIS, Andreazzi MFS, Menezes JSB, et al., organizadoras. A mercantilização da saúde em debate: as organizações sociais no Rio de Janeiro. Rio de Janeiro: Universidade do Estado do Rio de Janeiro; Rede Sirius; 2015. p. 33-9.

14. Pó MV. Institucionalidade e desafios da regulação na área da saúde no Brasil. In: Santos NR, Amarante PDC. Gestão pública e relação público-privado na saúde. Rio de Janeiro: CEBES; 2011. p. 243-266.

15. Brasil. Lei Complementar $\mathrm{n}^{\circ} 101$, de 4 de maio de 2000. Estabelece normas de finanças públicas voltadas para a responsabilidade na gestão fiscal e dá outras providências. Diário Oficial da União. 5 Maio 2000.

16. Behring ER. Trabalho e Seguridade Social: o neoconservadorismo nas políticas sociais. São Paulo: Corte; 2008.

17. Bodstein R, Souza RG. Relação público e privado no setor saúde: tendências e perspectivas na década de 90. In: Goldenberg P, Marsiglia RMG, Gomes MHA. O clássico e o novo: tendências, objetos e abordagens em ciências sociais e saúde. Rio de Janeiro: Fiocruz; 2003. p. 289-309.

18. Morais HMM, Albuquerque MSV, Oliveira RS, et al. Organizações Sociais da Saúde: uma expressão fenomênica da privatização da saúde no Brasil. Cad. Saúde Pública. 2018; 34(1):e00194916.

19. Donadone JC, Baggenstoss S. Intermediários e as novas configurações no tecido organizacional brasileiro: Um estudo sobre as organizações sociais de saúde. Temp. Soc. 2017; 29(1):130-149.

20. Alcântara CM. Serviços sociais autônomos e a administração pública brasileira. Revista de Direito Adm. Const., 2009; 37(9):175-197. 
21. Leite AMGN. Organizações sociais de saúde e controle externo: uma análise a partir do Tribunal de Contas de Pernambuco [dissertação]. Recife: Fundação Oswaldo Cruz, Centro de Pesquisas Aggeu Magalhães; 2014.

22. Mendonça LR, Machado Filho CAP. Governança nas organizações do terceiro setor: considerações teóricas. Revista de Adm. 2004; 39(4):302-308.

23. Pacheco HF, Gurgel Júnior GD, Santos FAS, et al. Las organizaciones sociales como modelo de gestión de la asistencia sanitaria en Pernambuco, Brasil: percepciones de los gestores. Interface (Botucatu). 2016; 20(58):585-95.

24. Duarte LS. Desenvolvimento desigual e a regionalização do SUS: uma análise territorial dos recursos financeiros para as redes de atenção à saúde no Estado de São Paulo (2009-2014) [tese]. São Paulo: Universidade de São Pau$10 ; 2016$.

25. Duarte LS, Mendes AN, Louvison MCP. O processo de regionalização do SUS e a autonomia municipal no uso dos recursos financeiros: uma análise do estado de São Paulo (2009-2014). Saúde debate. 2018; 42(116):25-37.

26. Lima LD, Albuquerque MV, Scatena JHG, et al. Arranjos regionais de governança do Sistema Único de Saúde: diversidade de prestadores e desigualdade espacial na provisão de serviços. Cad. Saúde Pública. 2019; 35(supl2):e00094618.

27. Thomson CR, Mckee M. Financing and planning of public and private not-for-profit hospitals in the European Union. Health Policy. 2004; 67(3):281-291.

28. Maarse H. The Privatization of Health Care in Europe: Na Eight-Country Analysis. J. Health Politic. Polic. Law. 2006; 31(5):1014-982.

29. Mendes AN, Marques RM, Leite MG, et al. Financiamento da saúde: análise dos gastos estaduais e municipais do Estado de São Paulo. Brasília, DF: Ipea; 1999. (Projeto BRA 97/03).

30. Brasil. Emenda Constitucional $n^{\circ} 29$, de 13 de setembro de 2000. Altera os arts. 34, 35, 156, 160, 167 e 198 da Constituição Federal e acrescenta artigo ao Ato das Dis- posições Constitucionais Transitórias, para assegurar os recursos mínimos para o financiamento das ações e serviços públicos de saúde. Diário Oficial da União. 14 Set 2000.

31. Estado de São Paulo. Comissão Intergestores Bipartite. Deliberação CIB n ${ }^{\circ}$ 153/2007. A Comissão Intergestores Bipartite - SP, reunida em 19 de julho de 2007 referendou o reconhecimento de 64 Regiões de Saúde com respectivos colegiados regionais e os $17 \mathrm{DRS}$, enquanto macro-regiões com respectivas Comissões Intergestoras de abrangência macro-regional, conforme disposto no Anexo 1. Diário Oficial do Estado de São Paulo. 21 Set 2007.

32. São Paulo (estado). Comissão Intergestores Bipartite. Deliberação CIB no 4/2012. Considerando, a 50a Reunião ordinária do Colegiado de Gestão Regional de Saúde do Alto Tietê, realizada em 06/12/2011, que aprovou a fusão da Região de Saúde do Alto Tietê e da Região de Saúde de Guarulhos. Diário Oficial do Estado de São Paulo. 27 Jan 2012.

33. São Paulo (estado). Secretaria da Fazenda e Planejamento. Sistema de Informações Gerenciais da Execução Orçamentária (Sigeo). [internet]. [acesso em 2018 set 27]. Disponível em: https://www.fazenda.sp.gov.br/SigeoLeil31/Paginas/FlexConsDespesa.aspx.

34. European Commission. Health and Economic Analysis for an Evaluation of the Public Private Partnership in Health Care Delivery across EU. Bruxelas: European Union; 2013.

35. Barbosa NB, Elias PEM. As organizações sociais de saúde como forma de gestão público/privado. Ciênc. Saúde Colet. 2010; 15(5):2483-2495.

36. São Paulo (estado). Secretaria da Saúde. Portal Financeiro do Gestor. [internet]. [acesso em 2019 abr 2]. Disponível em: http://www.portalfinanceirodogestor.saude.sp.gov.br/.

Received on $02 / 11 / 2020$

Approved on 08/22/2020

Conflict of interests: non-existent

Financial support: non-existent 